\title{
A STUDY OF NUTRIENT FORAMINA IN HUMAN UPPER LIMB LONG BONES
}

\author{
Pratyusha Challa1, Rakesh Kumar Nanna ${ }^{2}$
}

${ }_{1}^{1}$ Assistant Professor, Department of Anatomy, Guntur Medical College, Guntur, Andhra Pradesh, India.

${ }^{2}$ Consultant Radiologist, MAX Diagnostic \& Interventional Center, Guntur, Andhra Pradesh, India.

\section{BACKGROUND}

ABSTRACT

Nutrient foramina are cavities that conduct nutrient arteries and peripheral nerves on the shaft of long bones. Long bones receive most of the interosseous blood supply from nutrient arteries and sometimes through the periosteal vessels.

The aim of this study was to determine the common location, direction \& number of nutrient foramina of upper limb long bones.

\section{MATERIALS \& METHODS}

This is descriptive study of a total 150 human upper limb long bones $\{50$ humeri, 50 radii \& 50 ulnae $\}$ taken from Department of Anatomy, Guntur Medical College, Guntur and each was studied for location, direction \& number of nutrient foramina.

\section{RESULTS}

In humerus, a single nutrient foramen was found in $78 \%$ and double in $22 \%$ of bones, of them $62 \%$ foramina were on antero-medial surface, $25 \%$ on medial border, $5 \%$ on anterior border, $5 \%$ on posterior surface \& $3 \%$ on lateral border. $87 \%$ of nutrient foramina were in middle third of shaft of humerus. All radii had single nutrient foramen, of them $70 \%$ were on anterior surface $\& 30 \%$ on interosseous border. $74 \%$ of nutrient foramina were in middle third \& $26 \%$ were in upper third of shaft of radius. $98 \%$ of ulnae had single nutrient foramen \& $2 \%$ had double nutrient foramina, of them $78.4 \%$ were on anterior surface, $11.8 \%$ on posterior surface, $5.9 \%$ on interosseous border $\& 3.9 \%$ on anterior border. $88.2 \%$ of nutrient foramina were in middle third \& $11.8 \%$ in upper third of bone. All nutrient foramina were directed away from the growing end i.e., towards the elbow.

\section{CONCLUSION}

The study of nutrient foramina is of clinical importance in surgical procedures like orthopedic transplant techniques \& microvascular bone transfer procedures.

\section{KEY WORDS}

Nutrient Foramen, Upper Limb Long Bones, Foraminal Index.

HOW TO CITE THIS ARTICLE: Challa P, Nanna RK. A study of nutrient foramina in human upper limb long bones. J. Evolution Med. Dent. Sci. 2019;8(09):610-612, DOI: 10.14260/jemds/2019/135

\section{BACKGROUND}

Nutrient foramen is defined as the largest of the foramina present on the shaft of long bone allowing nutrient artery to enter the bone. ${ }^{1}$ The nutrient artery is the principal source of blood supply to a long bone \& particularly important during its active growth period in the embryo, fetus, as well as during the early phase of ossification. ${ }^{2}$ Long bones are supplied by four sets of arterial system- nutrient artery, epiphyseal, metaphyseal and periosteal arteries. The nutrient artery obliquely penetrates the shaft at their entrance point \& angulation being relatively constant. Once it reaches the medullary cavity, divide into ascending, descending branches \& supply bone marrow, inner two-thirds of compact bone. ${ }^{3}$ Reduction of blood flow to bone leads to ischemia of the metaphysis \& growth plate. 4

The direction of the nutrient foramen is away from the growing end of the bone, they seek the elbow and flee from the knee $^{5}$, showing varying directions in both limbs, this is because one end of the limb bone grows faster than the other.

'Financial or Other Competing Interest': None.

Submission 06-01-2019, Peer Review 16-02-2019,

Acceptance 22-02-2019, Published 04-03-2019.

Corresponding Author:

Dr. Pratyusha Challa,

D. No. 26-34-22/4, 10 th Line,

A. T. Agraharam, Guntur-522004,

Andhra Pradesh, India.

E-mail: dr.pratyusha04@gmail.com

DOI: $10.14260 /$ jemds $/ 2019 / 135$

\section{(c) $(i) \Theta$}

A considerable interest in studying nutrient foramen resulted not only from morphological, but also from clinical aspects. Nutrient foramen reflects to a certain degree the bone vascularization. ${ }^{6}$ Some pathological bone conditions such as developmental abnormalities, fracture healing, acute hematogenic osteomyelitis are closely related to the vascular system of the bone. The data is also helpful in procedures like bone grafting, tumour resection \& transplantations techniques.7,8

There is still a need for a greater understanding of the direction, location \& number of in nutrient foramina in human upper limb long bones. So, the aim of the present study is to record the direction, location \& number of nutrient foramina in long bones of upper limb.

\section{MATERIALS \& METHODS}

The descriptive study was conducted in Department of Anatomy, Guntur medical college, Guntur. The material consists of 50 humeri, 50 radii \& 50 ulnae. All bones are normal with no pathological changes. Age \& sex characteristics of the bones studied were unknown.

The nutrient foramina were observed with help of a hand lens, they were identified by their elevated margins $\&$ by the presence of a distinct groove proximal to them.

For each bone-

1. Total length of the bone was measured using Hepburn osteometric board.

2. The number of nutrient foramina were observed on the shaft.

3. Surface of bone on which nutrient foramen was located. 
4. Location of nutrient foramen in relation with the length of the bone by calculating.

Foraminal Index

- $\quad \mathrm{FI}=\mathrm{DU} / \mathrm{TL} \times 100$ \{Hughes, Shulman\}.

- $\quad \mathrm{FI}=$ Foramina index.

- $\mathrm{DU}=$ Distance from upper end to nutrient foramen.

- $\mathrm{TL}=$ Total length of bone.

Depending on FI, Position of Nutrient Foramen was divided into 3 Types

1. Upper third - FI up to 33.33

2. Middle third - FI from 33.34 to 66.66

3. Lower third - FI above 66.67

5. A fine stiff wire was used to observe the direction \& obliquity of the nutrient canal of nutrient foramen.

RESULTS

\begin{tabular}{|c|c|c|}
\hline $\begin{array}{c}\text { Name of } \\
\text { the Bone }\end{array}$ & $\begin{array}{c}\text { No. of Bones with } \\
\text { Single NF }\end{array}$ & $\begin{array}{c}\text { No. of Bones with } \\
\text { Double NF }\end{array}$ \\
\hline Humerus & $39\{78 \%\}$ & $11\{22 \%\}$ \\
\hline Radius & $50\{100 \%\}$ & --- \\
\hline Ulna & $49\{98 \%\}$ & $1\{2 \%\}$ \\
\hline Table 1. Incidence of Number of Nutrient Foramina in \\
Upper Limb Long Bones \\
\hline
\end{tabular}

\begin{tabular}{|c|c|c|}
\hline $\begin{array}{c}\text { Location of Nutrient } \\
\text { Foramen in 50 Humeri }\end{array}$ & $\begin{array}{c}\text { Number of } \\
\text { Nutrient Foramen }\end{array}$ & Percentage \\
\hline Anteromedial Surface & 38 & $62 \%$ \\
\hline Medial Border & 15 & $25 \%$ \\
\hline Lateral Border & 2 & $3 \%$ \\
\hline Posterior Border & 3 & $5 \%$ \\
\hline Posterior Surface & 3 & $5 \%$ \\
\hline Table 2. Percent Distribution of Location of Nutrient \\
Foramen In 50 Humeri \\
\hline
\end{tabular}

\begin{tabular}{|c|c|c|}
\hline $\begin{array}{c}\text { Location of Nutrient } \\
\text { Foramen in 50 Radii }\end{array}$ & $\begin{array}{c}\text { Number of } \\
\text { Nutrient Foramen }\end{array}$ & Percentage \\
\hline Anterior Surface & 35 & $70 \%$ \\
\hline Interosseous Border & 15 & $30 \%$ \\
\hline Table 3. Percent Distribution of Location of Nutrient \\
Foramina In 50 Radii \\
\hline
\end{tabular}

\begin{tabular}{|c|c|c|}
\hline $\begin{array}{l}\text { Location of Nutrient } \\
\text { Foramen in } 50 \text { Ulnae }\end{array}$ & \begin{tabular}{|c|} 
Number of \\
Nutrient Foramen
\end{tabular} & Percentage \\
\hline Anterior Surface & 40 & $78.4 \%$ \\
\hline Posterior Surface & 6 & $11.8 \%$ \\
\hline Interosseous Border & 3 & $5.9 \%$ \\
\hline Anterior Border & 2 & $3.9 \%$ \\
\hline $\begin{array}{r}\text { Table 4. Percent Di } \\
\text { For }\end{array}$ & O UIn & f Nutrient \\
\hline
\end{tabular}

\begin{tabular}{|c|c|c|c|}
\hline $\begin{array}{c}\text { Name of the } \\
\text { Bone }\end{array}$ & $\begin{array}{c}\text { Upper } \\
\text { Third }\end{array}$ & $\begin{array}{c}\text { Middle } \\
\text { Third }\end{array}$ & $\begin{array}{c}\text { Lower } \\
\text { Third }\end{array}$ \\
\hline Humerus & $3\{5 \%\}$ & $53\{87 \%\}$ & $5\{8 \%\}$ \\
\hline Radius & $13\{26 \%\}$ & $37\{74 \%\}$ & --- \\
\hline Ulna & $6\{11.8 \%\}$ & $45\{88.2 \%\}$ & --- \\
\hline
\end{tabular}

Table 5. Percentage Distribution of Different Locations of Nutrient Foramina According to Foraminal Index in Upper Limb Long Bones

All nutrient foramen directed towards elbow i.e., away from growing end.
There was no change in the obliquity of canal whether they are in the center or at the peripheral of the bone.

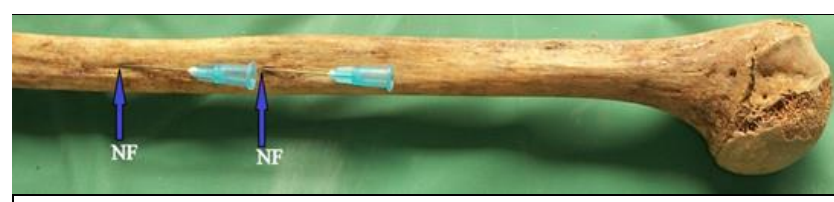

Figure 1. Humerus Showing Double Nutrient Foramina

\{Nf\}, Both on Anteromedial Surface of The Shaft, Both Directing Downwards (Towards Elbow)
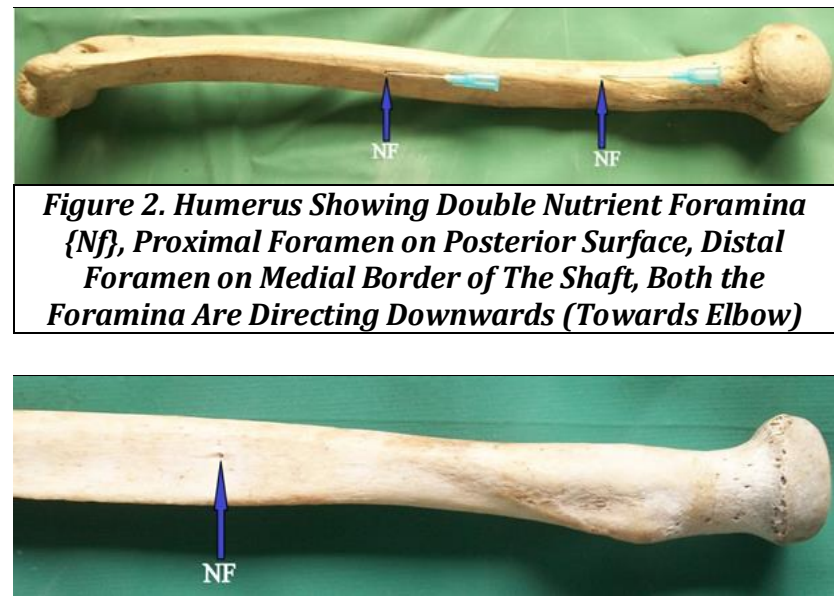

Figure 3. Radius Showing Single Nutrient Foramen $\{N F\}$ On Anterior Surface of The Shaft, Directing Upwards

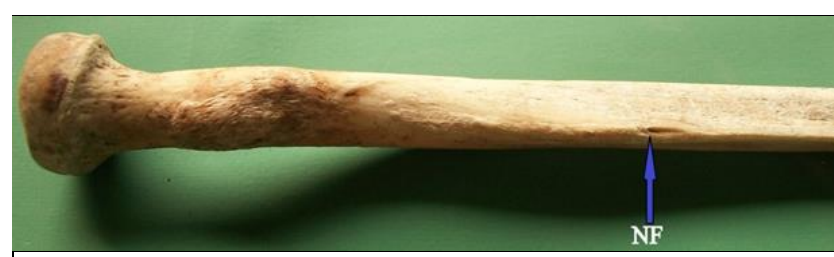

Figure 4. Radius Showing Single Nutrient Foramen $\{N F\}$ On Interosseous Border of The Shaft, Directing Upwards

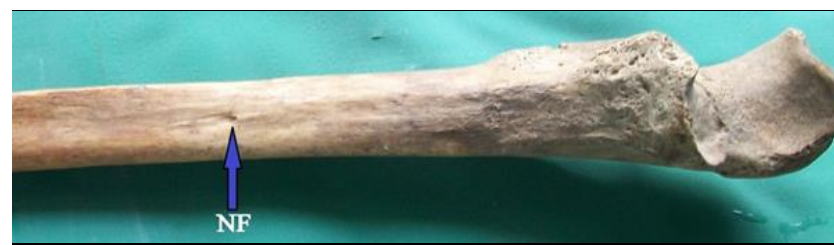

Figure 5. Ulna Showing Single Nutrient Foramen $\{N F\}$ On Anterior Surface of The Shaft, Directing Upwards

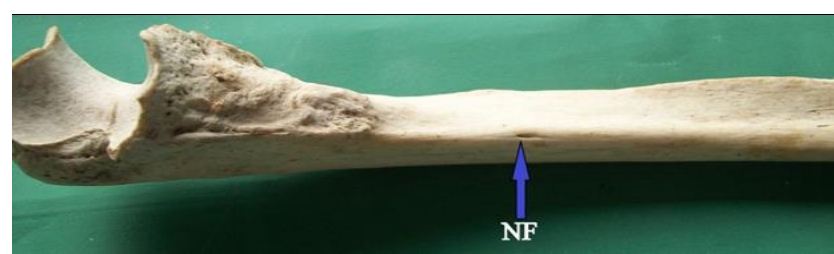

Figure 6. Ulna Showing Single Nutrient Foramen $\{N F\}$ On Anterior Border of The Shaft, Directing Upwards

\section{DISCUSSION}

Number of Nutrient Foramina

In the present study, in humerus single nutrient foramen had a higher percentage $\{78 \%$ \} compared to that of double $\{22 \%\}$. Many authors like Chandrasekaran S, Shanthi $\mathrm{KC}^{9}\{76.7 \%\}$, Bhojaraja VS et al $10\{77 \%\}$, Longia GS et al 11 \{85\%\} reported similar results. Absence of nutrient foramen was reported by 
some authors like Ukoha UU et al $^{12}\{26 \%\}$, Longia GS et al ${ }^{11}$ $\{2 \%\}$, Bhojaraja VS et al ${ }^{10}\{3 \%\}$. Kizilkanat E et al ${ }^{7}$ observed 4 nutrient foramina in $1 \%$ of humeri.

In the present study, all radii examined had a single nutrient foramen similar to that of Forriol Campos $\mathrm{F}$ et al. ${ }^{4}$ Some authors like Veeramuthu. $\mathrm{M}$ et al,13 Longia GS et al,11 Kizilkanat E et al, 7 Dr. Meenakshi Parthasarathy et al ${ }^{14}$ reported single nutrient foramen in more than $90 \%$ radii and remaining had double nutrient foramen. Radii without nutrient foramen were also observed by Dr. Meenakshi Parthasarathy et al ${ }^{14}\{4.2 \%\}$, Ukoha UU et al ${ }^{12}\{16 \%\}$.

In the present study in ulnae, $98 \%$ had single nutrient foramen similar to most authors. Dr. Meenakshi Parthasarathy et al, ${ }^{14}$ Ukoha UU et al ${ }^{12}$ found ulna without nutrient foramen. Longia GS et al ${ }^{11}$ reported ulna with 3 nutrient foramina.

\section{Position of Nutrient Foramina}

In the present study, humeri had most of the nutrient foramina on anteromedial surface $\{62 \%\}$ followed by medial border $\{20 \%\}$. Similar findings are reported by Kizilkanat E et $\mathrm{al}^{7}$ $\{62 \%\}$, Murlimanju BV et al ${ }^{15}\{60 \%\}$, Dr. Meenakshi Parthasarathy et al ${ }^{14}\{60 \%\}$. Asharani SK, Ningaiah $A^{16}$ observed more nutrient foramina on medial border $\{57 \%\}$ than anteromedial surface $\{32 \%\}$.

In radius $70 \%$ of nutrient foramina were on anterior surface \& $30 \%$ on interosseous border.

In ulna $78.4 \%$ of nutrient foramina were on anterior surface.

Many authors stated that most of nutrient foramina were on anterior surface in both radius \& ulna.

In the present study most of the nutrient foramina were in middle third of bone \{humerus- $87 \%$, radius- $74 \%$, ulna$88.2 \%$ \} which correlates with study of many authors. Longia GS et al,11 Mysorekar VR,17 Veeramuthu. $M$ et al ${ }^{13}$ observed most of the nutrient foramina in middle third of radius ulna.

According to Murlimanju BV et a,15 Dr. Meenakshi Parthasarathy et $\mathrm{al}^{14}$ in humerus more than $70 \%$ of nutrient foramina were seen in $3 / 5^{\text {th }}$ part of bone, in radius \& ulna more than $85 \%$ of nutrient foramina were seen in $2 / 5^{\text {th }}$ part of bone.

\section{Direction of Nutrient Foramina}

This study follows the dictum "To the elbow I go, from the knee I flee'.

In humerus the nutrient foramina were directed distally \& in radius, ulna they were directed proximally. Similar observations are reported by Shulman SS18 \& Longia GS et al. ${ }^{11}$ Ukoha UU et al $^{12}$ reported a radius with nutrient foramen directed distally.

\section{CONCLUSION}

In upper limb long bones, a single nutrient foramen on flexor surface in middle third of the shaft is common. All the foramina were directed towards elbow. The present study confirmed previous reports. Exact number, position \& direction of nutrient foramina are important to avoid damage to the nutrient vessels during surgical procedures like bone grafting, microsurgical vascularized bone transplantation and fracture management. Delayed or non-union following trauma may be directly related to the absence of nutrient arteries entering the bone.

\section{REFERENCES}

[1] Berard, Arch, Gener. De Med II Serie 1835;2(7):176-83.

[2] Lewis OJ. The blood supply of developing long bones with special reference to the metaphyses. J Bone Joint Surg Br 1956;38-B(4):928-33.

[3] Datta AK. The sclerous tissue. In: Principles of general anatomy. $6^{\text {th }}$ edn. Kolkata: K. P. Basu Publishing Co., 2007: p. 75-6.

[4] Campos FF, Pellico GL, Alias GM, et al. A study of the nutrient foramina in human long bones. Surg Radiol Anat 1987;9(3):251-5.

[5] Patake SM, Mysorekar VR. Diaphysial nutrient foramina in human metacarpals and metatarsals. J Anat 1977;124(Pt 2):299-304.

[6] Skawina A, Wyczolkowski M. Nutrient foramina of humerus, radius and ulna in human fetuses. Folia Morphol (Warsz) 1987;46(1-2):17-24.

[7] Kizilkanat E, Boyan N, Ozsahin ET, et al. Location, number and clinical significance of nutrient foramina in human long bones. Ann Anat 2007;189(1):87-95.

[8] Kirschner MH, Menck J, Hennerbichler A, et al. Importance of arterial blood to the femur and tibia for transplantation of vascularized femoral diaphysis and knee joints. World J Surg 1998;22(8):845-52.

[9] Chandrasekaran S, Shanthi KC. A study on the nutrient foramina of adult humerii. J Clin Diagn Res 2013;7(6):975-7.

[10] Bhojaraja VS, Kalthur SG, Dsouza AS. Anatomical study of diaphyseal nutrient foramina in human adult humerus. Arch Med \& Health Sci 2014;2(2):165-9.

[11] Longia GS, Ajmani ML, Saxena SK, et al. Study of diaphyseal nutrient foramina in human long bones. Acta Anat (Basel) 1980;107(4):399-406.

[12] Ukoha UU, Umeasalugo KE, Nzeako HC, et al. A study of nutrient foramina in long bones of Nigerians. National Journal of Medical Research 2013;3(4):304-8.

[13] Veeramuthu M, Elangovan M, Manoranjitham. Nutrient foramina: a study in the long bones of human upper extremities. Int J Anat Res 2017;5(3.3):4394-9.

[14] Parthasarathy M, Sharmadhakl, Pushpalatha M, et al. Morphological and topographical anatomy of nutrient foramina in human upper limb long bones and their surgical importance. IOSR Journal of Dental and Medical Sciences 2016;15(8):80-5.

[15] Murlimanju BV, Prasanth KU, Prabhu LV, et al. Morphological and topographical anatomy of nutrient foramina in human upper limb long bones and their surgical importance. Rom J Morphol Embryol 2011;52(3):859-62.

[16] Asharani SK, Ningaiah A. A study on the nutrient foramen of humerus. Int J Anat Res 2016;4(3):2706-9.

[17] Mysorekar VR. Diaphysial nutrient foramina in human long bones. J Anat 1967;101(Pt 4):813-22.

[18] Shulman SS. Observations of the nutrient foramina of the human radius and ulna. Anat Rec 1959;134:685-97. 